\title{
Chapter 5 \\ A Mobile Pilot Plant for the Recovery of Precious and Critical Raw Materials
}

\author{
Ionela Birloaga, Nicolo Maria Ippolito, and Francesco Vegliò
}

\begin{abstract}
In order to furtherly proceed with the recycling of raw materials from ewastes, PCBs must be treated in a hydrometallurgical process able to extract useful materials from them. This chapter presents some details of the hydrometallurgical pilot plant developed in FENIX.
\end{abstract}

\subsection{Introduction}

Precious metals (PMs) are crucial in the global economy as they are key constituents of a vast number of industrial products and processes. Large amounts of wastes with various contents of precious metals are generated every year. The wastes of electrical and electronic equipment know the worldwide largest increment. With the current growing trends there is estimated that this amount will arrive to 120 metric tons/year by 2050 and the consumption of the raw materials with be two-fold [1]. The waste printed circuit boards represent an important secondary resource of precious metals ( $\mathrm{Au}, \mathrm{Ag}, \mathrm{Pd}$ ) but also of base metals $(\mathrm{Cu}, \mathrm{Zn}, \mathrm{Ni}, \mathrm{Sn}, \mathrm{Pb}, \mathrm{Fe}, \mathrm{Al})$. As was expressed in the paper of Wand and Gaustad [2] the main economic drivers in the recycling of such waste, considering their concentrations and market price, are in the following order: $\mathrm{Au}, \mathrm{Pd}, \mathrm{Cu}, \mathrm{Ag}, \mathrm{Pt}, \mathrm{Sn}$ and Ni. According to the study of Golev et al. [3], the waste printed circuit boards represent about $40 \%$ of the metal recovery value from the entirely equipment.

The application of hydrometallurgical methods for recycling is preferred to pyrometallurgical methods, as the latter usually require high temperatures, produce harmful gases (such as $\mathrm{SO}_{2}$ ) and dust, and require high capital costs.

The first step of each hydrometallurgical recycling technique is represented by leaching. In order to achieve a high leaching efficiency of precious metals (PMs), the aqua regia, cyanide, thiol groups (thiourea, thiosulfate and thiocyanate), halides

\footnotetext{
I. Birloaga $(\varangle) \cdot$ N. M. Ippolito $\cdot$ F. Vegliò

Department of Industrial Engineering, Information and Economy, University of L'Aquila,

Monteluco di Roio, 67100 L'Aquila, Italy

e-mail: ionelapoenita.birloaga@univaq.it
} 
(chloride, iodide and bromide) with the presence of different oxidants (oxygen, ferric complexes, hydrogen peroxide, chlorine, bromide, iodine) are employed. The generations of highly polluted NOx and HCN gases, as well as various harmful elements in wastewater, have restricted the use of aqua regia and cyanide leaching systems. Table 5.1 presents a patent list of the hydrometallurgical processes with their brief overview that are used for base and precious metals recovery from WPCBs.

The hydrometallurgical processes have gained the largest interest of application for waste printed circuit boards treatment. In addition the circular economy principle stared to be of high interest for researchers that activate in the field of WPCBs treatment. However, till present, for recovery of all elements that are present within the structure of WPCBs was not possible to be obtained using hydrometallurgical processes.

For FENIX Project, the authors of this chapter have developed and tested the efficiency of two hydrometallurgical technologies for e-waste recycling at both laboratory and pilot levels. For both processes, commercially named GOLD REC 1 [9] and GOLD REC 2 [10], patent applications have been deposited at both Italian and European levels. The main core was to recover both precious and base metals content from electronic waste and to use them as material for the production of metallic powders (USE CASE 1), 3D printing filaments (USE CASE 3) and jewelries (USE CASE 2). Within this chapter the processes description and a summary of the activities undertaken for this core achievement are presented.

\subsection{Pilot Plant Design and Description by Process Performing}

The pilot plant was designed considering its installation in a real industrial environment logistically useful to carry out experimental tests for the researchers involved in this project. The advantages to operate in this industrial site are:

- Working in a real environmental context;

- Availability of the e-waste necessary for the pilot plant;

- Availability of several services (compressed air, grinding section, electricity, working men for dismantling, grinding and other technical operations)

In this way the following action were carried out:

a. Design and construction of the pilot plant;

b. Testing activities (comparing in parallel the same results with pilot lab-scale tests)

c. Production of some suitable amount of materials for their characterization and to be used for the other partners of the FENIX project.

The pilot plant was constructed within a container that was devised within three sections, namely: one section for operator and control panel, a second section that 
Table 5.1 Patents on waste printed circuit board treatment for recovery of both base and precious metals by hydrometallurgical procedures

\begin{tabular}{|c|c|c|}
\hline References & Description & Remarks \\
\hline [4] & 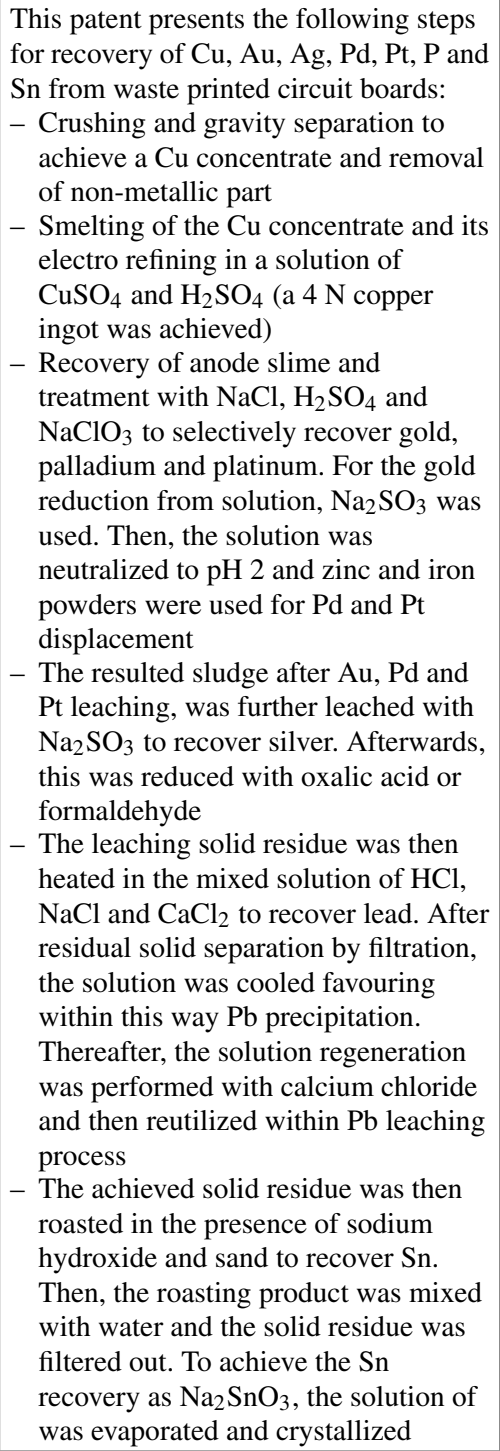 & $\begin{array}{l}\text { The authors have developed a } \\
\text { pyro-hydrometallurgical process that } \\
\text { was applied on waste printed circuits } \\
\text { boards after a physical-mechanical } \\
\text { pre-treatment. This procedure consists in } \\
\text { crushing of the boards and then } \\
\text { non-metallic parts separation by the } \\
\text { metallic ones by air classification. } \\
\text { However no data on the efficiency of this } \\
\text { technology have been provided within } \\
\text { this invention. Generally this process do } \\
\text { not allows the complete separation of } \\
\text { nonmetals and in addition, by } \\
\text { performing the smelting process, in case } \\
\text { of nonmetals presence, toxic gases are } \\
\text { produced. The authors sustain that all } \\
\text { the waste solutions have been } \\
\text { recirculated within the process }\end{array}$ \\
\hline
\end{tabular}


Table 5.1 (continued)

\begin{tabular}{|c|c|c|}
\hline References & Description & Remarks \\
\hline [5] & $\begin{array}{l}\text { The high grade printed circuit boards } \\
\text { have been treated in sulfuric acid and } \\
\text { hydrogen peroxide solution and then the } \\
\text { detached gold fingers have been treated } \\
\text { by two ways: (i) leaching with diluted } \\
\text { nitric acid for Cu removal and then the } \\
\text { purified gold is smelted and (ii) } \\
\text { dissolution of gold fingers within aqua } \\
\text { regia at a certain temperature, cooling of } \\
\text { solution, filtration, neutralization to pH } \\
\text { 1, addition of zinc particles for Au } \\
\text { cementation and then, to remove the } \\
\text { excess of zinc, the treatment of the } \\
\text { precipitate with diluted hydrochloric } \\
\text { acid at certain temperature is performed. } \\
\text { The resulted solution after copper } \\
\text { leaching with sulfuric acid and hydrogen } \\
\text { peroxide is concentrated by evaporation } \\
\text { and CuSO }{ }_{4} \text { crystals are achieved }\end{array}$ & $\begin{array}{l}\text { The current invention presents different } \\
\text { systems of reagents for } \mathrm{Cu} \text { and } \mathrm{Au} \\
\text { recovery. No discussion regarding the } \\
\text { waste solutions treatment or other } \\
\text { elements recovery is shown }\end{array}$ \\
\hline [6] & $\begin{array}{l}\text { Within the current invention the } \\
\text { researchers have firstly performed the } \\
\text { roasting of the boards, then the leaching } \\
\text { with sulfuric acid to extract the base } \\
\text { metals and then the solid residue } \\
\text { leaching with aqua regia at a certain } \\
\text { range of temperature. Thereafter, the } \\
\text { nitric acid was completely removed by } \\
\text { maintaining a certain level of } \\
\text { temperature. The achieved solution was } \\
\text { then used for selective precipitation of } \\
\text { Ag, Pd and Au }\end{array}$ & $\begin{array}{l}\text { Within this invention, the recovery of } \\
\text { precious metals after a thermal treatment } \\
\text { and base metals removal by acid } \\
\text { leaching was performed. Aqua regia was } \\
\text { also used within this patent for } \mathrm{Au}, \mathrm{Ag} \\
\text { and Pd dissolution and then, after } \\
\text { selective precipitation of all three } \\
\text { precious metals, the recirculation of } \\
\text { solution was achieved }\end{array}$ \\
\hline [7] & $\begin{array}{l}\text { The invention has as core to recover } \mathrm{Au} \\
\text { from minerals by leaching using an } \\
\text { iodine salt in presence of a carboxylic } \\
\text { acid (citric and acetic acid), boric acid } \\
\text { and optionally chlorine or bromine. The } \\
\text { leaching is performed on fine materials } \\
\text { in an electrochemical cell which allows } \\
\text { the increase of the ORP to oxidize the } \\
\text { iodide to iodine. Moreover, the inventors } \\
\text { have present as suitable alternatives the } \\
\text { addition of other oxidants }\left(\mathrm{H}_{2} \mathrm{O}_{2} \text {, }\right. \\
\text { NaOCl, } \mathrm{O}_{3} \text {, etc.) that are capable to } \\
\text { perform the oxidation }\end{array}$ & $\begin{array}{l}\text { The advantage of this process is the fact } \\
\text { that the solution can be regenerated and } \\
\text { therefore used many times. However, the } \\
\text { authors of this patent have not presented } \\
\text { any data on the precious metals recovery } \\
\text { from solution. In addition, there are also } \\
\text { other elements that can be leached } \\
\text { within this media. This fact is not } \\
\text { pointed out within this patent }\end{array}$ \\
\hline
\end{tabular}


Table 5.1 (continued)

\begin{tabular}{|c|c|c|}
\hline References & Description & Remarks \\
\hline [8] & $\begin{array}{l}\text { This patent presents the recovery of } \\
\text { precious and base metals from waste } \\
\text { printed circuit boards using the } \\
\text { following operations: } \\
\text { - Stripping process with concentrated } \\
\text { nitric acid, ferric chloride and ferric } \\
\text { nitrate to recover Sn and Pb and the } \\
\text { electronic components } \\
\text { - Shredding of the boards, eddy current } \\
\text { separation to achieve a high } \\
\text { concentrate of metals, treatment of the } \\
\text { concentrate with sulfuric acid and an } \\
\text { oxidant to recover Cu and Ni and then } \\
\text { electrolysis to achieve Cu and Ni } \\
\text { metals } \\
\text { - Dissolution of silver and palladium } \\
\text { from the solid residue of the previous } \\
\text { leaching process using nitric acid. } \\
\text { Then, by neutralization with NaOH } \\
\text { till pH 3-5, the palladium recovery } \\
\text { from solution was achieved. Silver } \\
\text { was recovered by addition of a } \\
\text { chloride salt } \\
\text { - The solid residue of previous step was } \\
\text { then leached with aqua regia for Au } \\
\text { leaching. The resulted solution was } \\
\text { further subjected to electrowinnig } \\
\text { process to recover metallic gold }\end{array}$ & $\begin{array}{l}\text { The current invention allows the } \\
\text { recovery of both precious and base } \\
\text { metals from WPCBs using various } \\
\text { reagents. However, due to the fact that } \\
\text { the patent is in Chinese language, was } \\
\text { difficult to understand well the entirely } \\
\text { process }\end{array}$ \\
\hline
\end{tabular}

has a chemical reactor (R101) with an useful volume of $200 \mathrm{~L}$ and a working temperature of $70^{\circ} \mathrm{C}$; this reactor was and it is used for leaching, precipitation and cementation; a filter press (FP 101) for filtration of the solutions that have more than $1 \mathrm{~g} / \mathrm{L}$ of solid content (e.g. solid residue of leaching or base metals precipitates) and a candle filter for solutions with a solid content lower than $1 \mathrm{~g} / \mathrm{L}$; two electrochemical cells (EC1 - for base metals and EC2 - for precious metals); one scrubber; the third section with 12 storing tanks (TK 101-106 for reagents and TK 107-112 for solutions and wastewater) (See Figs. 5.1, 5.2 and 5.3).

\subsubsection{GOLD REC 1 Process Description}

The hydrometallurgical process has started with the HydroWEEE EU Project and fully developed within the HydroWEEE DEMO EU Project. The current hydrometallurgical procedure, as is shown in Fig. 5.3, consists in the following operations: 


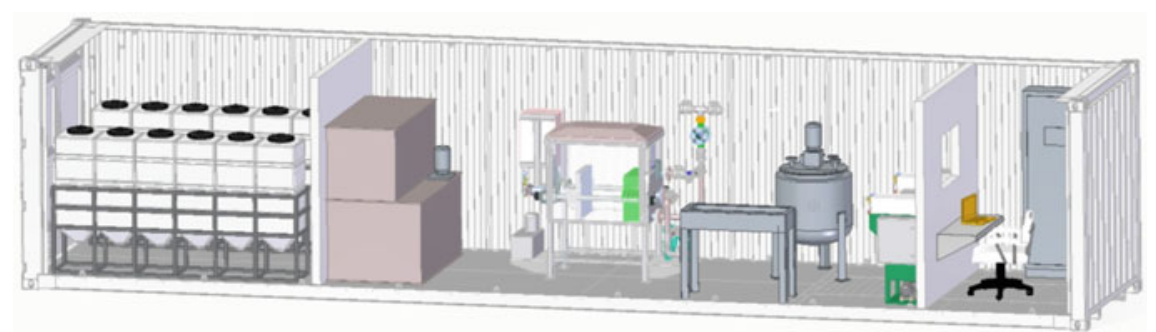

Fig. 5.1 FENIX hydrometallurgical plant-3D view

- The waste printed circuit boards are firstly subjected to a physical mechanical procedure where the $\mathrm{Al}$ - and Fe-based components are removed from PCBs surface. Then, the depopulated PCBs are shredded and milled to suitable particles sizes;

- The milled PCBs are then leached with water, sulfuric acid and hydrogen peroxide for the extraction of base metals by the precious metals (Eqs. 5.1 and 5.2).

$$
\begin{aligned}
& \mathrm{Cu}+\mathrm{H}_{2} \mathrm{SO}_{4}+\mathrm{H}_{2} \mathrm{O}_{2}=\mathrm{CuSO}_{4}+2 \mathrm{H}_{2} \mathrm{O} \\
& \mathrm{Sn}+\mathrm{H}_{2} \mathrm{SO}_{4}+\mathrm{H}_{2} \mathrm{O}_{2}=\mathrm{SnSO}_{4}+2 \mathrm{H}_{2} \mathrm{O}
\end{aligned}
$$

- The solid separation by the leach liquor is carried out by filtration process followed by washing with water. The resulted solution is subjected to a precipitation process for Sn precipitation. Then, also this solid precipitate is separated from solution by filtration and further washed with water. The solution achieved after Sn recovery is sent to an electrowinning cell for $\mathrm{Cu}$ recovery (Eq. 5.3).

$$
\mathrm{CuSO}_{4}+\mathrm{H}_{2} \mathrm{O}+2 \mathrm{e}^{-}=\mathrm{Cu}+\mathrm{H}_{2} \mathrm{SO}_{4}
$$

- Then, the resulted solution is recycled in the first leaching process for the leaching of another PCB material.

- The solid residue of base metals leaching process is involved into another leaching process with thiourea as reagent, ferric sulfate as oxidant in diluted sulfuric acid for $\mathrm{Au}$ and $\mathrm{Ag}$ dissolution (Reactions 5.4 and 5.5).

$$
\begin{gathered}
\mathrm{Au}+2 \mathrm{CS}\left(\mathrm{NH}_{2}\right)_{2}+\mathrm{Fe}^{3+} \rightarrow \mathrm{Au}\left[\mathrm{CS}\left(\mathrm{NH}_{2}\right)_{2}\right]_{2}++\mathrm{Fe}^{2+} \\
\mathrm{Ag}+3 \mathrm{CS}\left(\mathrm{NH}_{2}\right)_{2}+\mathrm{Fe}^{3+} \rightarrow \mathrm{Au}\left[\mathrm{CS}\left(\mathrm{NH}_{2}\right)_{2}\right]_{3}^{+}+\mathrm{Fe}^{2+}
\end{gathered}
$$

- Then, after removal of solid suspension form solution by filtration, the electrowinnig process is also applied on this solution for Au and Ag recovery (Eqs. 5.6 and 5.7). Once the process is finished, the solution is also recycled for leaching 


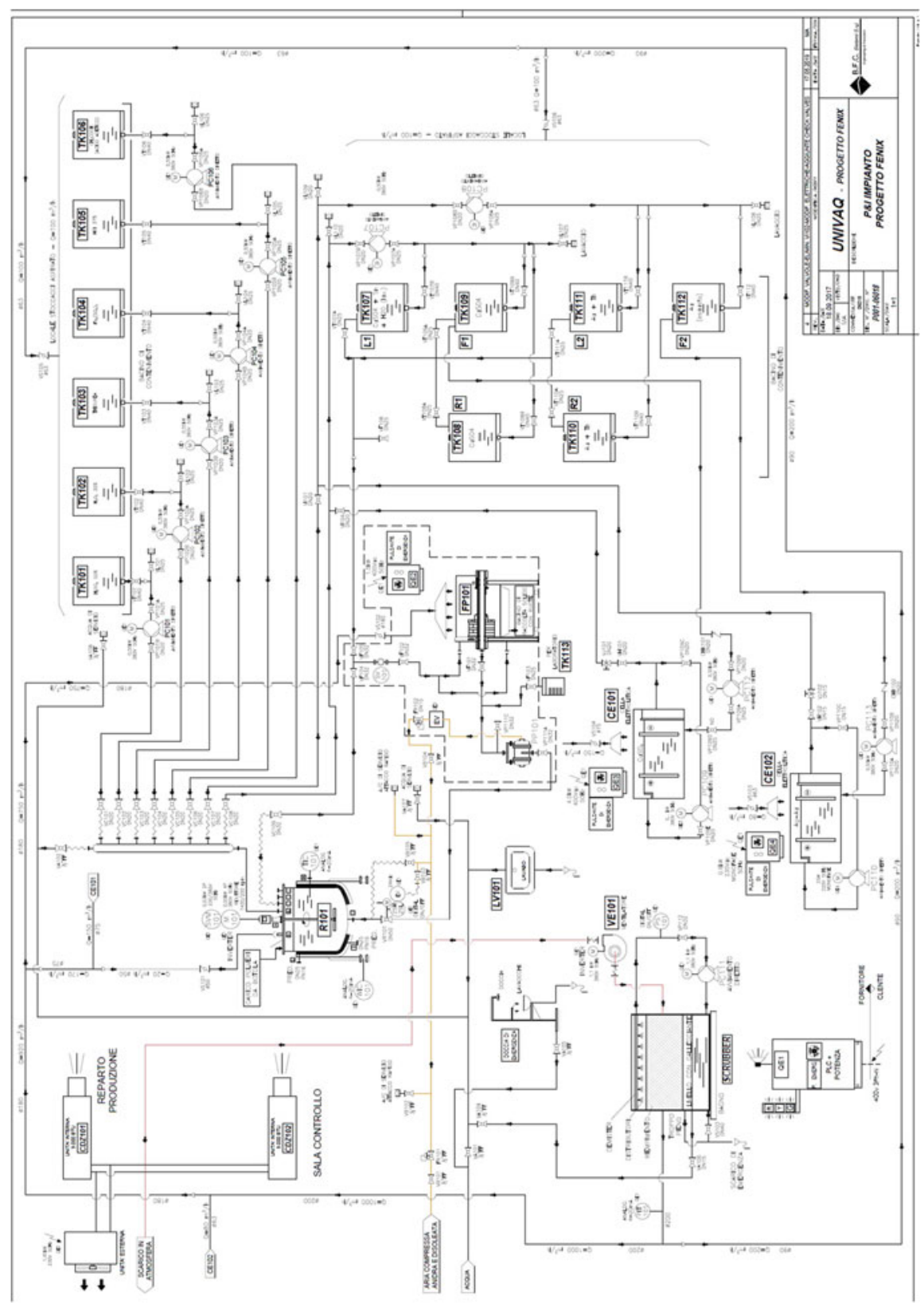

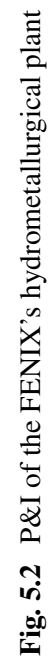




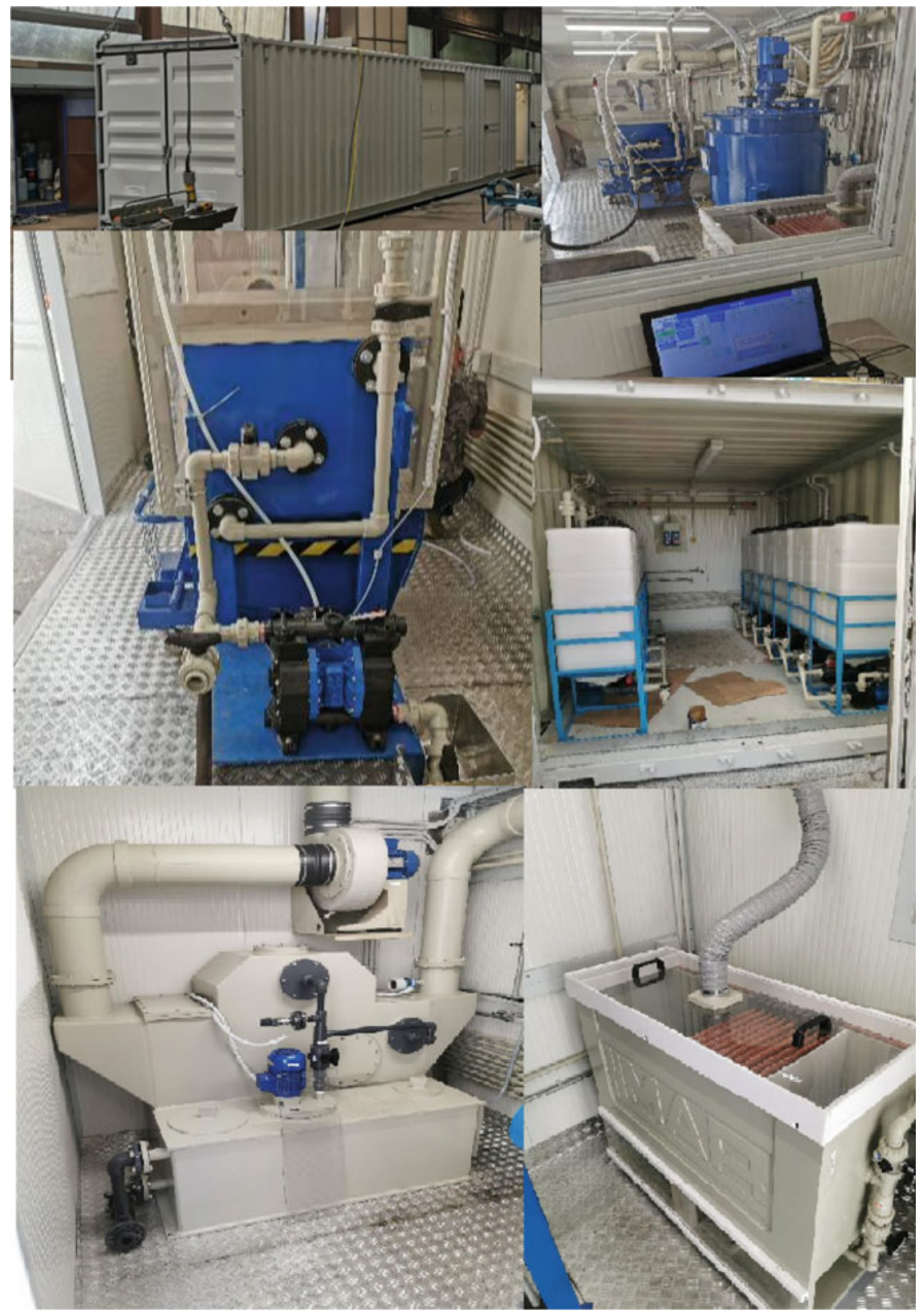

Fig. 5.3 FENIX's hydrometallurgical plant—real view 
of precious metals from other solid residue of base metals leaching process.

$$
\begin{gathered}
\mathrm{Au}\left(\mathrm{CSN}_{2} \mathrm{H}_{4}\right)_{2}^{+}+\mathrm{e}^{-}=\mathrm{Au}^{0}+2 \mathrm{CSN}_{2} \\
\mathrm{Ag}\left(\mathrm{CSN}_{2} \mathrm{H}_{4}\right)_{3}^{+}+\mathrm{e}^{-}=\mathrm{Ag}^{0}+3 \mathrm{CSN}_{2} \mathrm{H}_{4}
\end{gathered}
$$

- It is important to specify that solutions recycling after electrowinnig process will not be total. A part of these solutions are treated by proper technologies of waste water treatment. The treatment of the wastewater coming from the base metals recovery step consist in precipitation of the impurities with calcium hydroxide. The residual solution of precious metals recovery step is treated firstly with hydrogen peroxide and ferrous sulfate for degradation of organic complexes and then with calcium hydroxide for impurities precipitation. At the end of wastewater treatment process, the filtration is performed for solid removal from the treated water (Fig. 5.4).

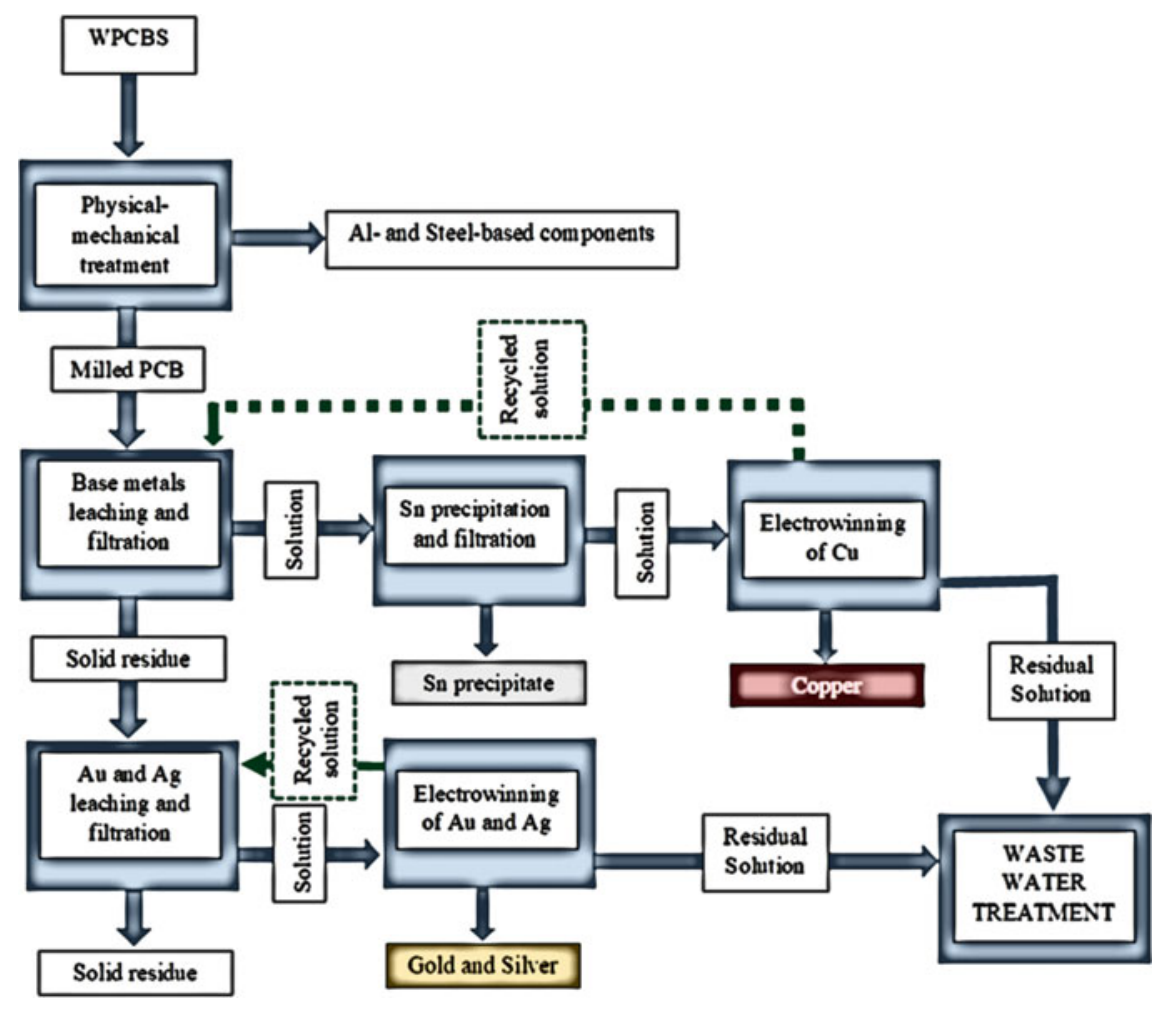

Fig. 5.4 Flow diagram of GOLD-REC 1 hydrometallurgical process 

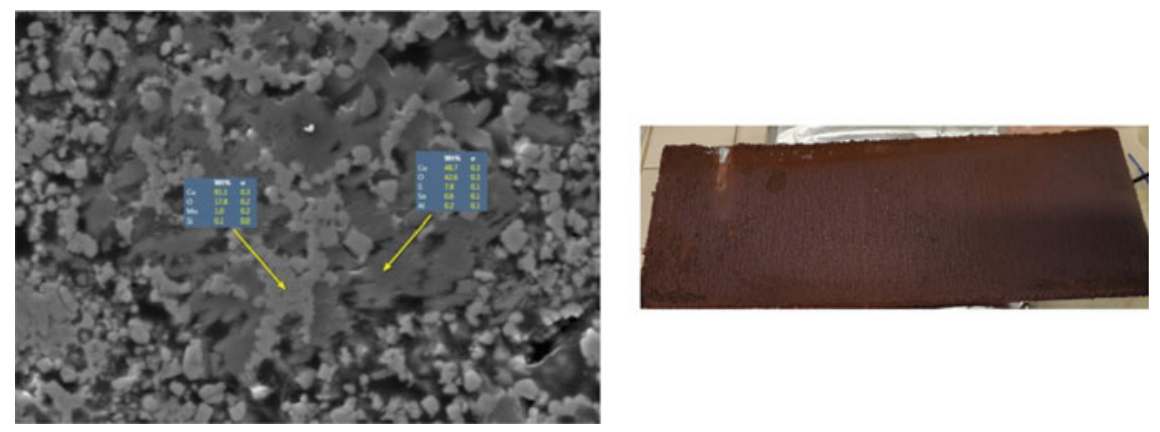

Fig. 5.5 SEM image and photography of copper deposit

Various tests of metals recovery with this hydrometallurgical technology have been applied on a milled sample of WPCBs of personal computers. Under the optimal conditions of the leaching process (solid concentration of $15 \%$, under continuous agitation for $2 \mathrm{~h}$ for each step and a reagents concentration of $1.8 \mathrm{M}$ of sulfuric acid and $20 \% \mathrm{vol} / \mathrm{vol}$ of hydrogen peroxide), which take place using the two-step counter current method, over $95 \%$ of $\mathrm{Cu}$ recovery and $60 \%$ for $\mathrm{Sn}$ have been achieved. The resulting solution was subjected to a coagulation process with polyamine solution in a concentration of $10 \% \mathrm{wt} . / \mathrm{vol}$. and $90 \%$ of tin content from solution was recovered. The obtained product had a tin concentration of about $50 \%$. Furthermore, the electrolysis process was performed using graphite as cathode and zirconium-titanium electrode as anode.

At the end of the process, the purity of $\mathrm{Cu}$ product was $89 \%$ and the determined power consumption was $2.39 \mathrm{kWh} / \mathrm{kg}$ of $\mathrm{Cu}$. The obtained copper deposit (Fig. 5.5) has been used for the additive manufacturing process (USE CASE 1).

\subsubsection{GOLD REC 2 Process Description}

The original process patented is presented in Fig. 5.6.

This hydrometallurgical process could be synthetically described as indicated in the follow:

- The chemical process can be applied on the e-waste without grinding (with whole WPCB as an example) avoiding important loss of precious metals also described in the literature;

- The process uses san unique step of metals dissolution with a chemical leaching using $\mathrm{HCl}, \mathrm{H}_{2} \mathrm{O}_{2}$, acetic acid in water solution at room temperature $\left(21^{\circ} \mathrm{C} \pm 3{ }^{\circ} \mathrm{C}\right.$ ) with a solid/liquid ratio of $10-20 \%$ (Eq. 5.8-5.15). The chloroacetic acid is produced by in situ chemical process within two steps: firstly, hydrochloric acid reacts with hydrogen peroxide and acetic acid to produce peracetic acid, water and chlorine (Eq. 5.8); in the second step chloroacetic acid and hydrochloric acid 


\section{E-WASTE}

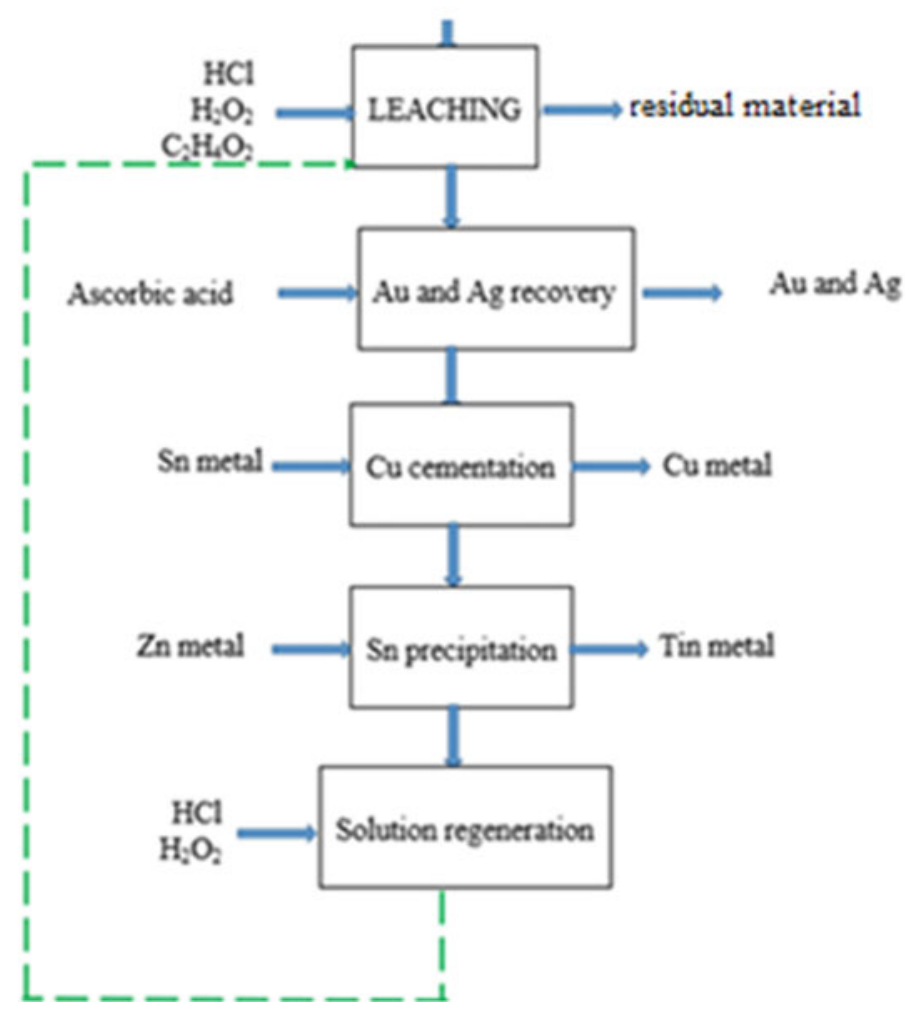

Fig. 5.6 Flow diagram of GOLD REC 2 hydrometallurgical process

are produced by the chlorination of the unreacted acetic acid (Eq. 5.9). The global reaction of this process is represented by Eq. 5.10.

$$
\begin{gathered}
2 \mathrm{HCl}+2 \mathrm{H}_{2} \mathrm{O}_{2}+\mathrm{C}_{2} \mathrm{H}_{4} \mathrm{O}_{2}=\mathrm{C}_{2} \mathrm{H}_{4} \mathrm{O}_{3}+3 \mathrm{H}_{2} \mathrm{O}+\mathrm{Cl}_{2} \\
\mathrm{C}_{2} \mathrm{H}_{4} \mathrm{O}_{4}+\mathrm{Cl}_{2}=\mathrm{C}_{2} \mathrm{H}_{3} \mathrm{ClO}_{2}+\mathrm{HCl} \\
\mathrm{HCl}+\mathrm{H}_{2} \mathrm{O}_{2}+\mathrm{C}_{2} \mathrm{H}_{4} \mathrm{O}_{2}=\mathrm{C}_{2} \mathrm{H}_{3} \mathrm{ClO}_{2}+2 \mathrm{H}_{2} \mathrm{O} \\
1.5 \mathrm{C}_{2} \mathrm{H}_{3} \mathrm{ClO}_{2}+1.5 \mathrm{HCl}+\mathrm{Au}=\mathrm{AuCl}_{3}+1.5 \mathrm{C}_{2} \mathrm{H}_{4} \mathrm{O}_{2} \\
\mathrm{C}_{2} \mathrm{H}_{3} \mathrm{ClO}_{2}+\mathrm{HCl}+2 \mathrm{Ag}=2 \mathrm{AgCl}+\mathrm{C}_{2} \mathrm{H}_{4} \mathrm{O}_{2}
\end{gathered}
$$




$$
\begin{aligned}
& \mathrm{C}_{2} \mathrm{H}_{3} \mathrm{ClO}_{2}+\mathrm{HCl}+\mathrm{Cu}=\mathrm{CuCl}_{2}+\mathrm{C}_{2} \mathrm{H}_{4} \mathrm{O}_{2} \\
& \mathrm{C}_{2} \mathrm{H}_{3} \mathrm{ClO}_{2}+\mathrm{HCl}+\mathrm{Sn}=\mathrm{SnCl}_{2}+\mathrm{C}_{2} \mathrm{H}_{4} \mathrm{O}_{2} \\
& \mathrm{C}_{2} \mathrm{H}_{3} \mathrm{ClO}_{2}+\mathrm{HCl}+\mathrm{Ni}=\mathrm{NiCl}_{2}+\mathrm{C}_{2} \mathrm{H}_{4} \mathrm{O}_{2} \\
& \mathrm{C}_{2} \mathrm{H}_{3} \mathrm{ClO}_{2}+\mathrm{HCl}+\mathrm{Pb}=\mathrm{PbCl}_{2}+\mathrm{C}_{2} \mathrm{H}_{4} \mathrm{O}_{2} \\
& \mathrm{C}_{2} \mathrm{H}_{3} \mathrm{ClO}_{2}+\mathrm{HCl}+\mathrm{Zn}=\mathrm{ZnCl}_{2}+\mathrm{C}_{2} \mathrm{H}_{4} \mathrm{O}_{2}
\end{aligned}
$$

- Precious (Au and $\mathrm{Ag}$ ) and base metals $(\mathrm{Cu}, \mathrm{Sn}, \mathrm{Zn}, \mathrm{Ni}, \mathrm{Pb})$ are dissolved leaving the WPCB with mainly epoxy resins and fiberglass structure intact (with some residues of metals);

- The liquid solution is easily separated from the S/L system and selective reductionprecipitations steps are considered in the process to recover the dissolved metals. These steps are synthetically described in the follow:

a. Reduction and precipitation of Au chloride to its metallic form by ascorbic acid;

$$
\mathrm{AuCl}_{3}+1.5 \mathrm{C}_{6} \mathrm{H}_{8} \mathrm{O}_{6}=\mathrm{Au}+3 \mathrm{HCl}+1.5 \mathrm{C}_{6} \mathrm{H}_{6} \mathrm{O}_{6}
$$

b. Cooling the solution to less than $15^{\circ} \mathrm{C}$ for precipitation of $\mathrm{AgCl}$;

c. Selective reduction and precipitation of $\mathrm{Cu}$ by metallic $\mathrm{Sn}$ or co-reduction of both copper and tin ions with iron metal;

$$
\begin{aligned}
& \mathrm{CuCl}_{2}+\mathrm{Sn}=\mathrm{SnCl}_{2}+\mathrm{Cu} \\
& \mathrm{CuCl}_{2}+\mathrm{Fe}=\mathrm{FeCl}_{2}+\mathrm{Cu} \\
& \mathrm{SnCl}_{2}+\mathrm{Fe}=\mathrm{FeCl}_{2}+\mathrm{Sn}
\end{aligned}
$$

d. Reduction and precipitation of $\mathrm{SnCl}_{2}$ by metallic $\mathrm{Zn}$;

$$
\mathrm{SnCl}_{2}+\mathrm{Zn}=\mathrm{ZnCl}_{2}+\mathrm{Sn}
$$


e. Exploitation of the residual solution for its recycling within the process or by adding iron in order to produce a $\mathrm{FeCl}_{2}-\mathrm{FeCl}_{3}$ solution useful for coagulation processes in the treatment of wastewaters;

2. The main products are: Au (after melting process in an inductive electrical oven adding some slug compound), $\mathrm{AgCl}, \mathrm{Cu}$ and $\mathrm{Sn}$ in powder forms (mainly in the range of 10-90 $\mu \mathrm{m}$ ) and a residual chloride solution that can be regenerated by make-up with proper reagents concentration or treated with iron metal to achieve a high concentrated iron solution (extensively and usually utilized in the coagulation processes in wastewater treatments);

Various tests have been conducted at both laboratory and pilot levels. These were carried out on various streams, namely: RAM modules, PCBs of mobile phones and CPU. The runs were performed using the following conditions: $3.5 \mathrm{M}$ of $\mathrm{HCl}$, $10 \%$ wt./vol. of $\mathrm{C}_{2} \mathrm{H}_{4} \mathrm{O}_{2}, 5 \%$ wt./vol. of $\mathrm{H}_{2} \mathrm{O}_{2}, 15-20 \%$ of solid concentration, room temperature, $3 \mathrm{~h}$. Under these conditions, recovery yields between 60 and $95 \%$ were achieved for $\mathrm{Au}, \mathrm{Ag}, \mathrm{Cu}$ and $\mathrm{Sn}$ content of the three kind of waste. Not complete dissolution is achieved since the process is performed in whole material. The waste materials (RAM modules and PCB of mobile phone) have entrapped within their layers and components these elements. Therefore, not complete exposition of elements to the leaching media is realized. The results carried out within the hydrometallurgical plant revealed a recovery of about $50-75 \%$ for these four elements. The process of reduction with ascorbic acid had an efficiency of over $95 \%$ for Au recovery at both pilot and laboratory levels. Figure 5.7 presents the photographic aspects of one of
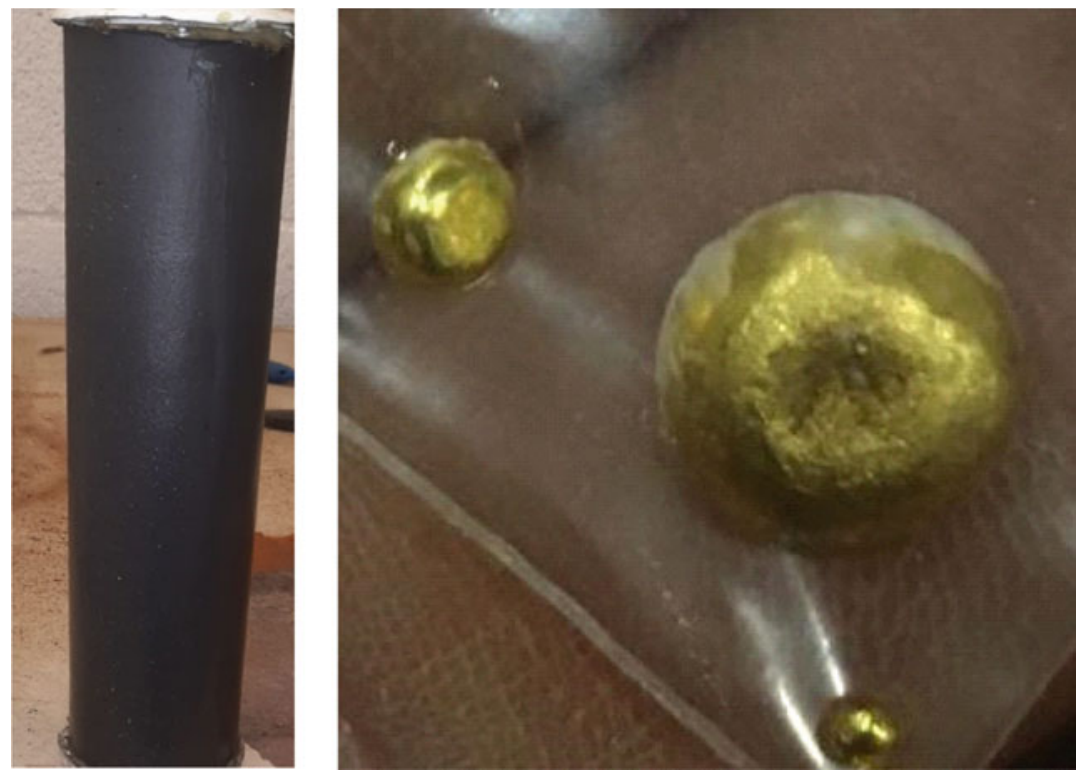

Fig. 5.7 Photographic aspect of Au product after precipitation and thermal refining 


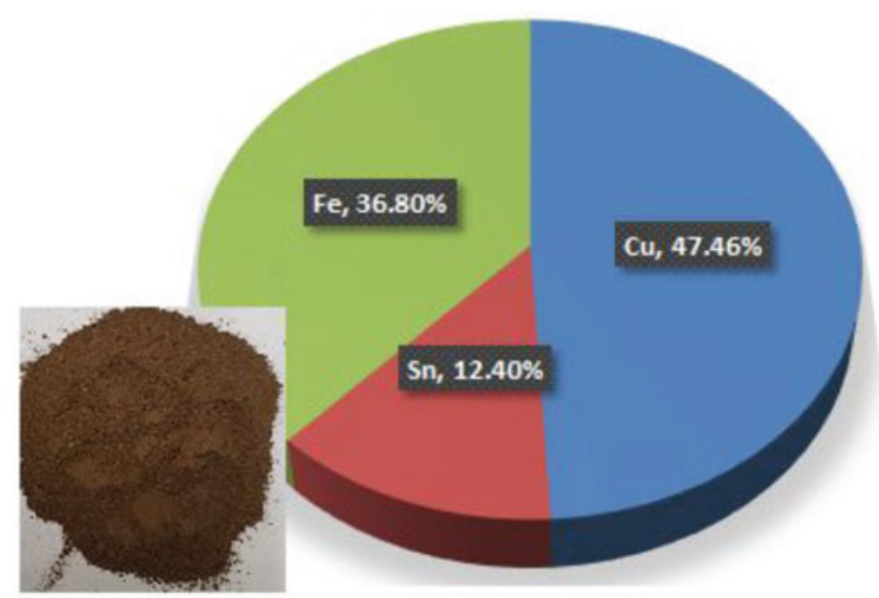

Fig. 5.8 Copper metal powder composition

the Au precipitates recovered at pilot level and final achieved product after thermal refining.

The further step of $\mathrm{AgCl}$ precipitation from solution by cooling revealed over $75 \%$ of recovery at laboratory scale after $3 \mathrm{~h}$ of reaction. At pilot level, Ag was coprecipitated during the copper cementation process. This was mainly since the plant does not have a cooling system. The copper recovery was performed either with Sn metal or Fe metal powders at laboratory scale level. The runs have been carried out at different stoichiometric amounts of both base metals and the optimal results in terms of recovery from solution and purity of products was achieved with tin metal at a stoichiometric amount of 0.8 ( $82 \%$ of recovery and $97 \%$ of purity). This is mainly since tin metal has close value to copper within the reactivity series of metals. The copper recovery with Fe revealed over $99 \%$ of recovery of copper at a stoichimetric excess of $45 \%$ and a purity of $84 \%$. At pilot level, the produced copper powder (Fig. 5.8) had a copper content of about 50\% with Fe and Sn as main impurities,

The achieved gold and copper products have been used for jewelry (USE CASE 2) and filaments (USE CASE 3) production.

\subsection{Conclusion}

In order to achieve a circular economy for metals, FENIX Project, has as one of the main cores to perform the recovery of base and precious metals from e-wastes and to reuses them for manufacturing of new products. For this reason, two hydrometallurgical processes have been tested at both laboratory and small industrial levels. There 
have been performed various experiments and according to the results achieved at pilot level, both technologies must be further improved to achieve better recovery degrees and properties of final products.

\section{References}

1. The World Economic Forum. (2019). A New Circular Vision for Electronics, Time for a Global Reboot-Report (p. 24).

2. Wang, X., \& Gaustad, G. (2012). Prioritizing material recovery for end-of-life printed circuit boards. Waste Management, 32(10), 1903-1913.

3. Golev, A., Schmeda-Lopez, D. R., Smart, S. K., Corder, G. D., \& McFarland, E. W. (2016). Where next on e-waste in Australia? Waste Management, 58, 348-358.

4. Zhang, S., Li, B., Pan, D., Tian, J., \& Liu, B. (2012). Complete non-cyanogens wet process for green recycling of waste printed circuit board. US20120318681A1.

5. Zha, H., He, L., Wen, W., \& Liu, C. (2014). Process for recycling gold from waste circuit boards. CN104152696 (A).

6. Brunori, C., Fontana, D., Carolis, R. D., Pietrantonio, M., Pucciarmati, S., Guzzinati, R., \& Torelli, G. N. (2015). Hydrometallurgy process for the recovery of materials from electronic boards. WO2015052658A1.

7. Nelson, D., Scott, S., Doostmohammadi, M., \& Jafari, H. (2017). Methods, materials and techniques for precious metal recovery. US20170369967A1.

8. Kaihua, X., \& Li, Y. (2011). Method for separating and recycling rare noble metals and waste plastics in waste circuit board. CN102240663 (A).

9. WO2018215967A1 Process for the hydrometallurgical treatment of electronic boards, Inventors: Birloaga, I., Vegliò, F., De Michelis, I., \& Ferella, F. (2018). Priority number IT201700057739 A-2017-05-26 (Gold-REC1)

10. WO2019229632A1, Hydrometallurgical method for the recovery of base metals and precious metals from a waste material, Inventors Birloaga, I., \& Vegliò, F. (2019). Priority number IT201800005826A-2018-05-29 (Gold-REC2)

Open Access This chapter is licensed under the terms of the Creative Commons Attribution 4.0 International License (http://creativecommons.org/licenses/by/4.0/), which permits use, sharing, adaptation, distribution and reproduction in any medium or format, as long as you give appropriate credit to the original author(s) and the source, provide a link to the Creative Commons license and indicate if changes were made.

The images or other third party material in this chapter are included in the chapter's Creative Commons license, unless indicated otherwise in a credit line to the material. If material is not included in the chapter's Creative Commons license and your intended use is not permitted by statutory regulation or exceeds the permitted use, you will need to obtain permission directly from the copyright holder.

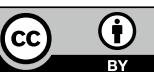

